\title{
Incisional Hernia Recurrence following "Vest-Over-Pants" or Vertical Mayo Repair of Primary Hernias of the Midline
}

\author{
Roland W. Luijendijk, M.D., ${ }^{1}$ Margot H.M. Lemmen, M.D., ${ }^{2}$ Wim C.J. Hop, Ph.D., ${ }^{3}$ \\ Jack C.J. Wereldsma, M.D., Ph.D. ${ }^{4}$ \\ ${ }^{1}$ Department of General Surgery, Leyenburg Hospital, Leyweg 275, 2545CH Den Haag, The Netherlands \\ ${ }^{2}$ Department of Plastic Surgery, University Hospital Rotterdam, Dijkzigt, Dr. Molewaterplein 40, 3015 GD Rotterdam, The Netherlands \\ ${ }^{3}$ Department of Epidemiology and Biostatistics, Medical School, Erasmus University, Dr. Molewaterplein 50, 3000 DR Rotterdam, The Netherlands \\ ${ }^{4}$ Department of General Surgery, Sint Franciscus Gasthuis, Kleiweg 500, 3045 PM Rotterdam, The Netherlands
}

\begin{abstract}
A series of 68 primary midline incisional hernias with a vertical Mayo repair was evaluated retrospectively. Patients without documented hernia recurrence following this repair were invited for physical examination. Life-table methods were used for statistical analysis. The 1-, 3-, 5-, and 10-year cumulative recurrence rates were $35 \%, 46 \%, 48 \%$, and $54 \%$, respectively. Also, generally accepted risk factors were studied. Multivariate analysis identified the size of the hernia $(p=0.02)$ and the use of steroids $(p=0.04)$ as the most important independent risk factors of first time recurrent incisional hernia. Considering the high recurrence rates found, the results of this study strongly suggest that the vest-over-pants repair should no longer be used for closure of midline incisional hernias.
\end{abstract}

Incisional hernias appear in at least $10 \%$ of patients with midline laparotomies [1]. Patients with an incisional hernia often complain of the aesthetic appearance or suffer from discomfort, pain, or intestinal obstruction [2]. A variety of operative procedures for incisional hernia repair have been in use, but the results are often disappointing. Five-year cumulative recurrence rates as high as $41 \%$ have been reported [3].

Mayo believed that a scar in one plane, from within out, was an important risk factor for developing a hernia $[4,5]$. He therefore advocated an overlapping repair in which each line of sutures is protected by normal structures. These sutures hold the structures in apposition, and the intraabdominal tension itself prevents displacement [4]. Mayo's technique is considered to be a major step in the history of hernia repair. Formerly, surgeons attempted to unite extensively dissected rectus muscles vertically in the midline, with poor results [4].

The present study was performed to evaluate the results of the vertical "vest-over-pants" Mayo repair. In addition, various potential risk factors for recurrent incisional hernia were analyzed.

\section{Patients and Methods}

The records of all patients with a vertical Mayo repair operated at the Department of Surgery of the Sint Franciscus Gasthuis

Correspondence to: J.C.J. Wereldsma, M.D., Ph.D.
Rotterdam between 1981 and 1990 were reviewed retrospectively. Because recurrent hernias are known to have higher recurrence rates $[3,6]$ and incisional hernias occur more often in the midline than in other vertical [1, 7-9] or transverse [7, 10-14] incisions, only patients with a primary hernia of the midline were selected for analysis. Patient-related factors of sex, age, obesity, chronic cough, prostatism, constipation, diabetes mellitus, history of oncologic disease, and use of steroids were noted. Obesity was measured using the Quetelet index. Operation-related factors, including surgical technique, suture materials, wound hematoma, wound infection, and the surgeon's experience (resident, consultant), were also analyzed. Hernia-related factors, such as the hernia-free interval, type of incision, previous hernia repairs, and the size and number of the hernias, were evaluated as well. Midline hernias were divided into upper, lower, umbilical $(\leq 3 \mathrm{~cm}$ proximal or distal from the umbilicus), or full length $(>3 \mathrm{~cm}$ proximal and distal from the umbilicus) hernias. Patients without documented hernia recurrence after the repair were invited for physical examination. In patients without recurrence, follow-up time was defined as the interval from hernia repair to present physical examination. In patients aware of a recurrence, the month of first detection was used as the time to the event. In patients having a recurrence of which they were not aware, the time to the recurrence was estimated as the time halfway between the most recent control visit and the study examination. Whenever physical examination was not possible due to death or other reasons, the most recent documented physical examination was used to determine hernia recurrence and follow-up time.

For incisional hernia repair the vertical Mayo technique was used, being a modification from the classic transverse Mayo technique for umbilical hernia repair $[4,5,15,16]$. This repair includes excision of the nonvital edges of the fascial defect and clearing of the rectal fascia over 3 to $5 \mathrm{~cm}$. Mattress sutures (1-0 Vicryl, polyglactin 910) are introduced approximately $2.5 \mathrm{~cm}$ from the margin of the aponeurosis on one side of the linea alba and 1 $\mathrm{cm}$ from the margin of the opposite side. When these sutures are tightened it draws one fascia underneath the other, creating a vertical fascial scar. The free margin of the overlapping flap is 
Table 1. Cumulative percentages of patients with recurrent incisional hernia following a primary vertical Mayo repair of the midline after $0-120$ months of follow-up.

\begin{tabular}{llll}
\hline $\begin{array}{l}\text { Months } \\
\text { after } \\
\text { operation }\end{array}$ & $\begin{array}{l}\text { Patients in follow-up } \\
\text { without hernia } \\
\text { recurrence (no.) }\end{array}$ & $\begin{array}{l}\text { Cumulative } \\
\text { recurrence } \\
\text { rate }(\%)\end{array}$ & $\begin{array}{l}\text { Standard } \\
\text { error } \\
(\%)\end{array}$ \\
\hline 0.5 & 68 & 7 & 3 \\
$1-1.5$ & 63 & 13 & 4 \\
6 & 40 & 29 & 5 \\
12 & 33 & 35 & 6 \\
24 & 30 & 39 & 6 \\
36 & 26 & 46 & 6 \\
48 & 21 & 46 & 6 \\
60 & 15 & 48 & 7 \\
120 & 5 & 54 & 8 \\
\hline
\end{tabular}

sutured to the surface of the opposite aponeurosis, creating a second suture line $[4,5,15,16]$.

Life-table methods were used for statistical analysis. Cumulative percentages of patients having a recurrence along time were calculated and compared using Kaplan-Meier curves and log rank tests, the latter including the trend test version [17]. Multivariate analysis of various factors was done using Cox regression. The $p$ values given are two-sided; $p=0.05$ was considered the limit of significance.

\section{Results}

A series of 68 patients was analyzed. This group comprised 31 men and 37 women with a mean age of 65 years (range 20-82 years). Follow-up examination varied from 0.5 to 152 months (mean 35 months). For cases without recurrence $(n=40)$, mean follow-up was 50 months (range 1-152 months). The cumulative recurrence rates after $1,3,5$, and 10 years were $35 \%, 46 \%, 48 \%$, and $54 \%$, respectively (Table 1 ).

Of the 28 with a recurrence, 9 patients $(32 \%)$ had a recurrence during the first month, 12 patients $(43 \%)$ after 1 month and within 1 year, 2 patients $(7 \%)$ during the second year, and 3 patients $(11 \%)$ during the third year. Hence most of the recurrences $(75 \%)$ occurred within the first postoperative year.

Univariate analysis of patient-related risk factors (Table 2) demonstrated that only the use of steroids was related $(p=0.05)$ to recurrence (Fig. 1). Of the hernia-related factors, full length resulted in more recurrences than the combined group of median upper, median lower, or umbilical incisions $(p=0.01)$, whereas there was no difference $(p=0.61)$ between the latter three groups. Also the size of the hernia correlated with the risk of recurrence in cases with a single defect. Smaller defects generally had a lower risk of recurrence $(p=0.03)$ (Fig. 2). Of the operation-related factors, none significantly correlated with recurrence. There was a trend, though, for a higher recurrence rate in patients who had had a wound infection $(p=0.09)$.

Multivariate analysis demonstrated that the size of the hernia for patients with a single defect and use of steroids were the most important factors predicting a recurrence. A doubling of the size of the defect resulted in a 1.6-fold increased recurrence rate ( $p=$ 0.02 ). The use of steroids led to a 2.9 -fold increased recurrence rate $(p=0.04)$. Full-length incisions generally had a higher recurrence rate when considered alone, but this factor was of no importance when adjusted for the size of the defect.
Table 2. Recurrence rates in relation to various risk factors in patients with a vertical Mayo repair of a primary incisional hernia of the midline.

\begin{tabular}{|c|c|c|c|c|}
\hline Factors & $\begin{array}{l}\text { No. of } \\
\text { pts. }^{a}\end{array}$ & $\begin{array}{l}\text { No. of pts. } \\
\text { with recurrence }\end{array}$ & $\begin{array}{l}5 \text {-Year } \\
\text { cumulative } \\
\text { recurrence } \\
\text { rate }(\%)\end{array}$ & $p$ \\
\hline \multicolumn{5}{|l|}{ Patient-related } \\
\hline \multicolumn{5}{|l|}{ Sex } \\
\hline Male & 31 & 16 & 64 & \multirow[t]{2}{*}{0.12} \\
\hline Female & 37 & 12 & 36 & \\
\hline \multicolumn{5}{|l|}{ Age } \\
\hline$\leq 65$ Years & 34 & 17 & 55 & \multirow[t]{2}{*}{0.43} \\
\hline$>65$ Years & 34 & 11 & 39 & \\
\hline \multicolumn{5}{|l|}{ Obesity $(\mathrm{Q} \geq 25)$} \\
\hline No & 27 & 10 & 46 & \multirow[t]{2}{*}{0.84} \\
\hline Yes & 39 & 18 & 50 & \\
\hline \multicolumn{5}{|l|}{ Cough } \\
\hline No & 55 & 22 & 47 & \multirow[t]{2}{*}{0.82} \\
\hline Yes & 13 & 6 & 51 & \\
\hline \multicolumn{5}{|l|}{ Constipation } \\
\hline No & 64 & 26 & 47 & \multirow[t]{2}{*}{0.97} \\
\hline Yes & 4 & 2 & 66 & \\
\hline \multicolumn{5}{|l|}{ Prostatism } \\
\hline No & 31 & 16 & 64 & \multirow[t]{2}{*}{ - } \\
\hline Yes & 0 & 0 & - & \\
\hline \multicolumn{5}{|l|}{ Diabetes } \\
\hline No & 65 & 27 & 49 & \multirow[t]{2}{*}{0.95} \\
\hline Yes & 3 & 1 & 33 & \\
\hline \multicolumn{5}{|l|}{ Oncology } \\
\hline No & 57 & 23 & 47 & \multirow[t]{2}{*}{0.99} \\
\hline Yes & 11 & 5 & 56 & \\
\hline \multicolumn{5}{|l|}{ Steroids } \\
\hline No & 59 & 22 & 44 & \multirow[t]{2}{*}{0.05} \\
\hline Yes & 9 & 6 & $\geq 72$ & \\
\hline \multicolumn{5}{|l|}{ Hernia-related } \\
\hline Incision & & & & \\
\hline Full length & 13 & 9 & 75 & \multirow[t]{4}{*}{$0.01^{b}$} \\
\hline Median upper & 29 & 11 & 48 & \\
\hline Median lower & 11 & 3 & 28 & \\
\hline Umbilical & 14 & 4 & 45 & \\
\hline Size $(\mathrm{cm})$ & & & & \\
\hline $1.5-3.0$ & $15^{c}$ & 4 & 31 & $0.03^{d}$ \\
\hline $3.1-6.0$ & $15^{c}$ & 7 & 44 & \\
\hline $6.1-12.0$ & $14^{c}$ & 8 & 73 & \\
\hline $12.1-25.0$ & $9^{c}$ & 5 & $\geq 78$ & \\
\hline Multiple & 14 & 4 & 42 & \\
\hline Operation-related & & & & \\
\hline Surgeon & & & & \\
\hline Resident & 15 & 5 & 38 & 0.56 \\
\hline Consultant & 45 & 21 & 56 & \\
\hline Both $^{e}$ & 8 & 2 & 25 & \\
\hline Postoperative infe & & & & \\
\hline No & 60 & 23 & 45 & 0.09 \\
\hline Yes & 8 & 5 & 75 & \\
\hline Hematoma & & & & \\
\hline No & 61 & 24 & 47 & 0.55 \\
\hline Yes & 7 & 4 & $\geq 57$ & \\
\hline
\end{tabular}

${ }^{a}$ Because of missing data, the numbers of patients do not always add up to 68 .

${ }^{b}$ Full length compared to other median incisions combined (difference among the latter three groups: $p=0.61$ ).

${ }^{c}$ Single fascial defects.

${ }^{d}$ Trend test.

${ }^{e}$ Operation performed by resident under assisting supervision of consultant.

\section{Discussion}

With respect to "vest-over-pants" incisional hernia repairs, van der Linden et al. [18] reported 26 recurrences among 47 repairs, 


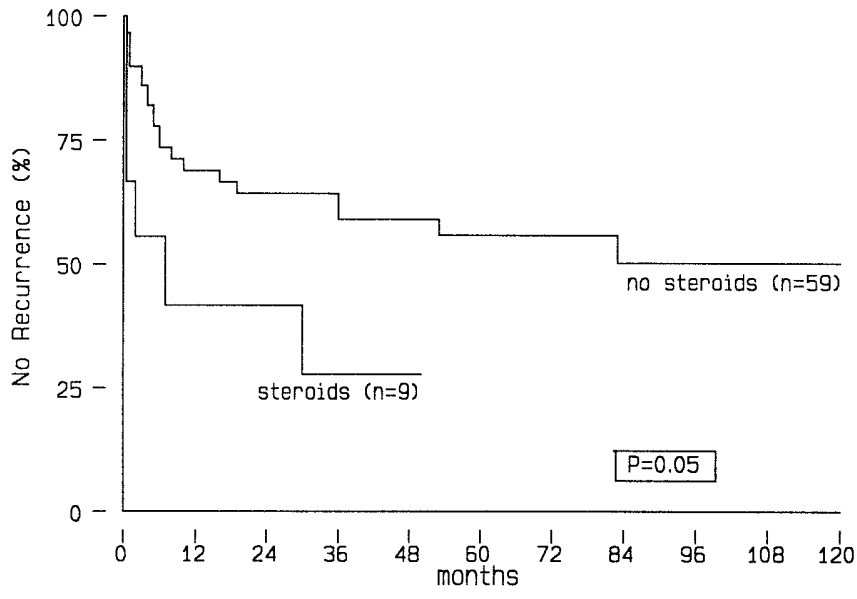

Fig. 1. Kaplan-Meier curves for recurrence of incisional hernia according to the use of steroids.

and Fischer and Turner [19] reported 11 recurrences for 57 repairs. A variety of incisions were included, however; and at that time life-table analysis was not yet performed. Because incisional hernias develop with time [20], and patients have variable lengths of follow-up, life-table methods are essential for studying hernia recurrence rates. Failure to do so may lead to underestimation of recurrence rates and therefore may result in erroneous conclusions. With respect to primary incisional hernia repair with various incisions and techniques but using life-table analysis, the literature reveals high cumulative recurrence rates (Langer et al. [6] reported a 10-year rate of $31 \%$ and Hesselink et al. [3] a 5-year rate of $41 \%$ ). Seeking better results, we deliberately changed our technique in 1980 to the vertical Mayo repair, hoping the doublebreasted vest-over-pants technique would serve our needs. The outcome, a 10-year cumulative recurrence rate of $54 \%$, is disappointing.

As with all suture techniques, the tension on the tissues might be responsible for these results, by increasing the risk of tissue ischemia and suture cut-out [21,22]. Due to the nature of the Mayo repair, which creates an overlap, this risk might be even more pronounced. Second, the use of absorbable suture material might have an influence [23, 24]. Absorbable 1-0 Vicryl sutures were used, which maintain their tensile strength for approximately 2 to 3 weeks. In this series, $32 \%$ recurred within the first postoperative month, suggesting that permanent suture material, by maintaining its tensile strength throughout the life of the wound, might be advantageous. However, Pollock and Evans [25] showed that early fascial separation may be responsible for a subsequent incisional hernia as well. If so, early loss of tensile strength might not be a major influence. Prospective studies studying primary abdominal wall closure have not yet given a clear answer [23, 24].

With respect to risk factors, wound infection is often considered to be the most important factor contributing to the development of incisional hernia [7, 10, 11, 14, 19, 21, 26-29]. In the present study we observed a higher (though not significantly) recurrence rate after wound infection. This nonsignificant finding may be due to the small number of patients with infection $(n=8)$ in this study. The size of the hernia was observed to be a significant factor for recurrence, confirming the findings of others. Hesselink et al.

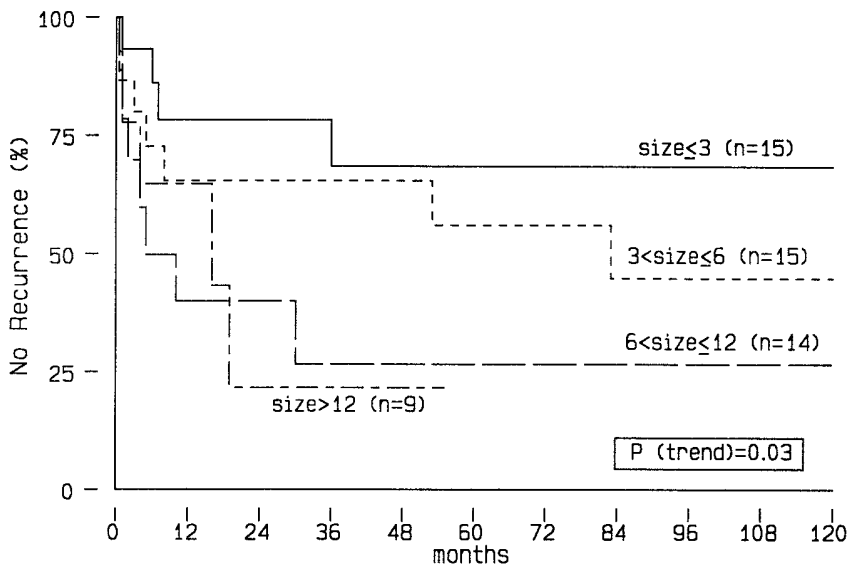

Fig. 2. Kaplan-Meier curves for recurrence of incisional hernia according to the size of the single lesion defect $(<3,3-6,6-12$, and $>12 \mathrm{~cm})$. Significantly fewer $(p=0.03)$ recurrences were found in patients with small hernias. The 5-year cumulative recurrence rates of these groups were $31 \%, 44 \%, 73 \%$, and $\geq 78 \%$, respectively.

[3] demonstrated that hernias smaller than $4 \mathrm{~cm}$ had a significantly lower recurrence rate than larger ones. The lower tension associated with repair of small hernias may be responsible. The use of steroids was identified as a risk factor, for small and large hernias, which may reflect the fact that steroids delay wound healing [10].

At this time no consensus has been reached about whether, how, and when to operate on a patient with an incisional hernia. Data from this and other series certainly are worrisome, making many surgeons hesitant to undertake a repair. Incisional hernia, however, is a significant source of morbidity, and delay in repair can have serious clinical consequences. Fascial defects, especially the small ones, predispose to incarceration or strangulation [10, 12]. The mortality rate of complicated incisional hernia repair is approximately $1 \%$ [30]. Second, nonoperated hernias might increase in size [10], with increasing difficulty of repair and higher recurrence rates. Third, massive hernias may give rise to dystrophic ulceration of skin, chronic abdominal and back pain, and respiratory complications due to diaphragmatic dysfunction [12, 31]. Therefore more efficacious techniques of hernia repair are needed.

Since the mid-1980s several series have shown low recurrence rates with inlay of prosthetic material [31-36], even in large defects, presumably due to the tension-free repair [21]. Although randomized trials are lacking, we now use prosthetic materials for repair of large defects $(>6 \mathrm{~cm})$. For smaller defects, an objective comparison between a one-layer approximating closure using nonabsorbable sutures and closure with intraperitoneal prosthetic material is currently being undertaken by means of a prospective randomized multicenter trial.

In conclusion, the size of the hernia and the use of steroids were identified as independent risk factors for first-time recurrent incisional hernias. The 5-year cumulative recurrence rates for hernias $<3 \mathrm{~cm}, 3$ to $6 \mathrm{~cm}, 6$ to $12 \mathrm{~cm}$, and $>12 \mathrm{~cm}$ differed significantly: $31 \%, 44 \%, 73 \%$, and $78 \%$, respectively. These high recurrence rates strongly indicate that the vest-over-pants repair should not be used for closure of midline incisional hernias. 


\section{Résumé}

Les résultats d'une série de 68 éventrations médianes traitées par la technique de Mayo ont été évalués rétrospectivement. Tous les patients sans récidive prouvée ont été revus et ont fait l'objet d'un nouvel examen physique. La méthode des courbes de survie a été utilisée pour analyser les résultats. Le taux cumulatif des récidives à $1,3,5$, et 10 ans a été respectivement de $35,46,48$ et 54 pourcent. Les facteurs de risque, en analyse multivariée, étaient la taille de la hernie $(\mathrm{p}=0.02)$ et l'utilisation de corticoïdes $(\mathrm{p}=$ 0.04 ). En tenant compte du taux élevé de récidive, les résultats de cette étude suggèrent fortement que la technique de verticale Mayo ne doit pas être utilisée pour les éventrations médianes.

\section{Resumen}

Se hizo la evaluaciòn retrospectiva de una serie de 68 casos de hernia incisional primaria de lìnea media sometidos a reparaciòn vertical de Mayo. Los pacientes con hernia recurrente documentada luego de este tipo de reparaciòn fueron llamados para examen fisico. Se utilizò el mètodo de las tablas de vida para el anàlisis estadìstico. Las tasas de recurrencia acumulativa a 1, 3, 5 y 10 años fueron $35,46,48$ y 54 por ciento, respectivamente. Tambièn se hizo el estudio de los factores de riesgo. El anàlisis multivariable identificò el tamaño de la hernia $(\mathrm{p}=0.02)$ y el uso de esteroides $(p=0.04)$ como los màs importantes factores independientes de riesgo de recurrencia de la hernia incisional. En consideraciòn a la alta tasa de recurrencia encontrada, los resultados del estudio sugieren fuertemente que la tècnica de vest-over-pants ("chaleco sobre pantalòn") no debe ser utilizada en la reparaciòn de hernias incisionales de lìnea media.

\section{References}

1. Cahalane, M.J., Shapiro, M.E., Silen, W.: Abdominal incision: decision or indecision? Lancet 21:148, 1989

2. Mudge, M., Hughes, L.E.: Incisional hernia: a 10 year prospective study of incidence and attitudes. Br. J. Surg. 72:70, 1985

3. Hesselink, V.J., Luijendijk, R.W., de Wilt, J.H.W., Heide, R., Jeekel, J.: Incisional hernia recurrence; an evaluation of risk factors. Surg. Gynecol. Obstet. 176:228, 1993

4. Mayo, W.J.: Radical cure of umbilical hernia. J.A.M.A. 48:1842, 1907

5. Mayo, W.J.: Remarks on the radical cure of hernia. Ann. Surg. 29:51, 1899

6. Langer, S., Christiansen, J.: Long-term results after incisional hernia repair. Acta Chir. Scand. 151:217, 1985

7. Ellis, H., Coleridge-Smith, P.D., Joyce, A.D.: Abdominal incisions: vertical or transverse? Postgrad. Med. J. 60:407, 1984

8. Cox, P.J., Ausobsky, J.R., Ellis, H., Pollock, A.V.: Towards no incisional hernias: lateral versus midline incisions. J. R. Soc. Med. 79:711, 1986

9. Guillou, P.J., Hall, T.J., Donaldson, D.R.: Vertical abdominal incisions: a choice? Br. J. Surg. 67:395, 1980

10. Baker, R.J.: Incisional hernia. In Hernia (3rd ed.), L.M. Nyhus, R.E. Condon, editors. Philadelphia, Lippincott, 1989, pp. 321-329

11. Larson, G.M., Vandertoll, D.J.: Approaches to repair of ventral hernia and full-thickness losses of the abdominal wall. Surg. Clin. North Am. 64:335, 1984

12. Santora, T.A., Roslyn, J.J.: Incisional hernia. Surg. Clin. North Am. 73:557, 1993

13. Lamont, P.M., Ellis, H.: Incisional hernia in re-opened abdominal incisions: an overlooked risk factor. Br. J. Surg. 75:374, 1988

14. Blomstedt, B., Welin-Berger, T.: Incisional hernias: a comparison between midline, oblique and transrectal incisions. Acta Chir. Scand. 138:275, 1972

15. Mayo, W.J.: An operation for the radical cure of umbilical hernia. Ann. Surg. 34:276, 1901

16. Harmel, R.P., Jr.: Umbilical hernia. In Hernia (3rd ed.), L.M. Nyhus, R.E. Condon, editors. Philadelphia, Lippincott, 1989, pp. 354-359

17. Peto, R., Pike, M.C., Armitage, P., Breslow, N.E., Cox, D.R., Howard, S.W., Mantel, N., McPherson, K., Peto, J., Smith, P.G.: Design and analysis of randomized clinical trials requiring prolonged observation of each patient. I. Introduction and design. Br. J. Cancer 34:585-612, 1976

18. Van der Linden, F.T.P.M., van Vroonhoven, T.J.M.V.: Long-term results after surgical correction of incisional hernia. Neth. J. Surg. 40(5):127, 1988

19. Fischer, J.D., Turner, F.W.: Abdominal incisional hernias: a ten-year review. Can. J. Surg. 17:202, 1974

20. Ellis, H., Gajraj, H., George, C.D.: Incisional hernias: when do they occur? Br. J. Surg. 70:290, 1983

21. George, C.D., Ellis H.: The results of incisional hernia repair: a twelve year review. Ann. R. Coll. Surg. Engl. 68:185, 1986

22. Urschel, J.D., Scott, P.G., Williams, H.T.G.: Etiology of late developing incisional hernias: the possible role of mechanical stress. Med. Hypoth. 25:31, 1988

23. Wissing, J.C., van Vroonhoven, T.J.M.V., Eeftinck Schattenkerk, M.: Fascia closure after midline laparotomy: results of a randomized trial. Br. J. Surg. 74:738, 1987

24. Lewis, R.T., Wiegand, F.M.: Natural history of vertical abdominal parietal closure: Prolene versus Dexon. Can. J. Surg. 32:196, 1989

25. Pollock, A.V., Evans, M.: Early prediction of late incisional hernias. Br. J. Surg. 76:953, 1989

26. Bucknall, T.E., Ellis, H.: Abdominal wound closure: a comparison of monofilament nylon and polyglycolic acid. Surgery 89:672, 1981

27. Bucknall, T.E., Cox, P.J., Ellis, H.: Burst abdomen and incisional hernia: a prospective study of 1129 major laparotomies. B.M.J. 284:931, 1982

28. Pollock, A.V., Greenall, M.J., Evans, M.: Single-layer mass closure of major laparotomies by continuous suturing. J. R. Soc. Med. 72:889, 1979

29. Houck, J.P., Rypins, E.B., Sarfeh, I.J., Juler, G.L., Shimoda, K.J.: Repair of incisional hernia. Surg. Gynecol. Obstet. 169:397, 1989

30. Heydorn, W.H., Velanovich, V.: A five-year U.S. Army experience with 36,250 abdominal hernia repairs. Am. Surg. 56:596, 1990

31. Stoppa, R.E.: The treatment of complicated groin and incisional hernias. World J. Surg. 13:545, 1989

32. Usher, F.C.: Hernia repair with Marlex mesh. Arch. Surg. 84:325, 1962

33. Larson, G.M., Harrower, H.W.: Plastic mesh repair of incisional hernias. Am. J. Surg. 135:559, 1978

34. Wantz, G.E.: Incisional hernioplasty with Mersilene. Surg. Gynecol. Obstet. 172:129, 1991

35. Validire, J., Imbaud, P., Dutet, D., Duron, J.J.: Large abdominal incisional hernias: repair by fascial approximation reinforced with a stainless steel mesh. Br. J. Surg. 73:8, 1986

36. Molloy, R.G., Moran, K.T., Waldron, R.P., Brady, M.P., Kirwan, W.O.: Massive incisional hernia: abdominal wall replacement with Marlex mesh. Br. J. Surg. 78:242, 1991 


\section{Invited Commentary}

\author{
Jean Henri Alexandre, M.D. \\ Department of General and Digestive Surgery, University of Paris, \\ Hôpital Broussals, Paris, France
}

Despite multiple efforts of the surgeon, a better choice of incision (more lateral and short than median and large), a better quality of suture, prophylaxis in obese patients by an intraabdominal resorbable prosthesis, and antibiotic prophylaxis incisional hernia appear to be a permanent and frequent (10\% of laparotomies) surgical problem. Multiple procedures have been proposed with and without a prosthesis.

Luijendijk et al. have evaluated the results of the vertical "vest-over-pants" Mayo procedure in 68 patients over a long period, with documented parameters and a strict follow-up. This excellent study with its acknowledged poor results represents an important contribution to the understanding of this illness.

Most recurrences (75\%) appear during the first year, and within 3 years most failures are obvious. Our experience concerning the time of recurrence is identical, as is the size of the hernia correlating with the risk of recurrence. For us obesity is a known determinant for choosing a surgical procedure. Because poor results without using a prosthesis are known in cases of large incisional hernias, with recurrence rates within 10 years from $30 \%$ to $54 \%$, we have decided, after the reports of Rives and Stoppa (in France) [1-3] and most of the surgeons of the European Group of Research and Study on Wall Surgery (GREPA), to select the procedures and insert a prosthesis when the size of hernia is $>10$ $\mathrm{cm}[4]$.

For small incisional hernias in the absence of a prosthesis, we always use (contrary to what is suggested in the Mayo repair study) nonabsorbable material, as for groin hernia surgery. The "tension-free" notion, which is accepted elsewhere, concerns cases of midline incisional hernia: It is the basis of the excellent Premont procedure [5] (using, after median suture, multiple short incisions on the anterior rectal fascia by three parallel vertical lines).

We have recently reported with Bouillot about 544 documented personal cases (GREPA, Paris, June 1996) our results of large incisional hernias $(>10 \mathrm{~cm})$. We divided our patients in two groups: those with large median incisional hernias and those with lateral and complex incisional hernias. The second group benefited from the principles applied in the first: excision of skin scar, sac, and deficient fascia; freeing the abdominal viscera; closure of a posterior sheath (peritoneum or both with a transverse apone- neurosis). Then we inserted a large mesh, fixed by multiple sutures, and closed the anterior rectal fascia with absorbable suture. We used a prosthesis in 252 of 388 median incisional hernias. The mortality rate was 2 of $252(2 \%)$, and morbidity was 42 of $252(16 \%)$ (superficial abscesses 9, hematomas 14, pulmonary infections 10 , phlebitis 2, parietal disunion 4, prosthesis removal 3. The mean follow-up was 42 months for $85 \%$ of patients. There were eight recurrences $(5 \%)$. The causes of recurrence were an incorrectly placed or too small prosthesis. For large lateral and complex incisional hernias (160 patients, 190 orifices) we performed 133 primary operations, with 21 recurrences; six patients had a third recurrence. There were 62 iliac, 68 subcostal or bisubcostal hernias, 34 lateral and medial hernias, 25 on colostomy, 14 lateral and 4 pararectal, 7 lumbar and transversal hernia, and 5 after Pfannenstiel operation. We have used 114 Dacron prostheses, 4 PTFE, and 5 resorbable prostheses for infection. In 11 cases two prostheses were inserted as in a sandwich; 29 patients have been operated on without mesh. The mortality rate was 1 of 160 and the morbidity 30 of 160 (18\%). Mean follow-up was 44 months in $85 \%$ of patients, with five recurrences among 160 patients (four were reoperated, all successfully).

In conclusion, the failure of large incisional hernia repair without using a prosthesis has been proved by the present excellent study. We share the conclusion of the authors that the procedure by "vertical Mayo repair" should no longer be used. The procedure using a prosthesis even in different procedures (intraperitoneal [6], posterior [3] anterior [7]) with a recurrence rate of less than $10 \%$ suggests that these methods are preferred.

\section{References}

1. Rives, J., Lardennois, B., Pire, J.C., Hobow, J.: Les grandes eventrations: importance du volet "abdominal" et des troubles respiratoires qui lui sont secondaires. Chirurgie 99:547, 1973

2. Rives, J., Pire, J.C., Flament, J.B., Palot, J., Body, C.: Le traitement des grandes éventrations. Chirurgie 151:635, 1985

3. Louis, D., Stoppa, R., Henry, X., Verhaeghe, P.: Les éventrations post-opératoires: a propos de 247 cas opérés. J. Chir. 22:523, 1985

4. Alexandre, J.H., Bouillot, J.L., Dupin, P., Maladry, D.: Pla ce de la prothèse de Dacron dans les éventrations multiorificelles et latérales. GREPA 8:45, 1986

5. Clotteau, J.E., Premont, M.: Cure par plastie aponévrotiques des éventrations abdominales: technique et résultats. GREPA 8:17, 1986

6. Adloff, M., Arnaud, J.P.: Surgical management of large incisional hernias by an intra-intraperitoneal Mersilene mesh and an aponeurotic graft. Surg. Gynecol. Obstet. 165:204, 1987

7. Chevrel, J.P., Flament, J.B.: Les éventrations de la paroi abdominale. Monographie du 92ème Congrès Français de Chirurgie, Paris, 1990 